\title{
Are soluble ST2 levels influenced by vitamin D and/or the seasons?
}

\author{
Vito Francic ${ }^{1}$, Martin Keppel ${ }^{2}$, Verena Schwetz ${ }^{1}$, Christian Trummer ${ }^{1}$, Marlene Pandis ${ }^{1}$, Valentin Borzan ${ }^{1}$, \\ Martin R Grübler ${ }^{1}$, Nicolas D Verheyen ${ }^{3}$, Marcus E Kleber ${ }^{4}$, Graciela Delgado ${ }^{4}$, Angela P MoissI ${ }^{4}$, \\ Benjamin Dieplinger ${ }^{5}$, Winfried März ${ }^{4,6}$, Andreas Tomaschitz ${ }^{7}$, Stefan Pilz ${ }^{1}$ and Barbara Obermayer-Pietsch ${ }^{1}$ \\ 'Division of Endocrinology and Diabetology, Department of Internal Medicine, Medical University of Graz, Graz, Austria \\ ${ }^{2}$ Department of Laboratory Medicine, Paracelsus Medical University, Salzburg, Austria \\ ${ }^{3}$ Division of Cardiology, Department of Internal Medicine, Medical University of Graz, Graz, Austria \\ ${ }^{4} \mathrm{~V}$ th Department of Medicine (Nephrology, Hypertensiology, Rheumatology, Endocrinology, Diabetology), Medical Faculty Mannheim, University of \\ Heidelberg, Mannheim, Germany \\ ${ }^{5}$ Department of Laboratory Medicine, Konventhospital Barmherzige Brueder Linz, Linz, Austria \\ ${ }^{6}$ Synlab Academy, Synlab Holding Germany GmbH, Heidelberg, Germany \\ ${ }^{7}$ Specialist Clinic of Rehabilitation Bad Gleichenberg, Bad Gleichenberg, Austria
}

Correspondence should be addressed to V Francic: vito.francic@medunigraz.at

\begin{abstract}
Objective: Cardiovascular disease manifestation and several associated surrogate markers, such as vitamin $D$, have shown substantial seasonal variation. A promising cardiovascular biomarker, soluble ST2 (sST2), has not been investigated in this regard - we therefore determined if systemic levels of SST2 are affected by seasonality and/or vitamin $\mathrm{D}$ in order to investigate their clinical interrelation and usability.

Design: SST2 levels were measured in two cohorts involving hypertensive patients at cardiovascular risk, the Styrian Vitamin D Hypertension Trial (study A; RCT design, 8 weeks 2800 IU cholecalciferol daily) and the Ludwigshafen Risk and Cardiovascular Health Study (LURIC; study B; cross-sectional design).

Methods: The effects of a vitamin D intervention on SST2 levels were determined in study A using ANCOVA, while seasonality of SST2 levels was determined in study B using ANOVA.

Results: The concentrations of SST2 remained unchanged by a vitamin $D$ intervention in study $A$, with a mean treatment effect (95\% confidence interval) of $0.1(-0.6$ to 0.8$) \mathrm{ng} / \mathrm{mL} ; P=0.761)$, despite a rise in $25(\mathrm{OH}) \mathrm{D}(11.3(9.2-13.5) \mathrm{ng} / \mathrm{mL}$; $P<0.001)$ compared to placebo. In study $B$, seasonal variations were present in $25(\mathrm{OH}) \mathrm{D}$ levels in men and women with or without heart failure ( $P<0.001$ for all subgroups), while SST2 levels remained unaffected by the seasons in all subgroups.

Conclusions: Our study provides the first evidence that systemic SST2 levels are not interrelated with vitamin D levels or influenced by the seasons in subjects at cardiovascular risk.
\end{abstract}

\section{Introduction}

A broad range of cardiovascular disease (CVD) has been observed to be influenced by seasonal variation. Various parameters, ranging from temperature changes to vitamin D deficiency, have been shown to play a potential role in this complex phenomenon (1). Indeed, according to population-based and epidemiological studies, cardiovascular events are more common in winter, which coincides not only with lower temperatures and with the https://ec.bioscientifica.com https://doi.org/10.1530/EC-19-0090 (c) 2019 The authors Published by Bioscientifica Ltd
Endocrine Connections (2019) 8, 691-700 
peak of several cardiovascular risk factors as well as their biomarker surrogates but also the seasonal prevalence of vitamin D deficiency $(1,2,3)$.

Soluble ST2 (sST2) is the truncated, soluble form of the ST2 receptor found in the circulation and functions as a decoy receptor, binding IL-33 and thereby inhibiting the effects of IL-33/ST2 signalling (4). This protein has been shown to be a promising prognostic cardiovascular biomarker (5). Elevated levels of sST2 have been associated with poor prognosis in myocardial infarction (6) and heart failure (HF) (7), with the risk of acute aortic dissection (8) as well as with subclinical brain injury and incident stroke (9).

Hypertension is one of the strongest risk factors for almost all cardiovascular diseases, including HF (10). Furthermore, coronary artery disease is known as a major risk factor for developing $\mathrm{HF}$ and its progression (11). sST2 has been most extensively researched in relation to $\mathrm{HF}$, but several studies have also shown potential for sST2 being a prognostic or diagnostic biomarker for disease deterioration in hypertensives or other patients at cardiovascular risk $(8,12,13,14,15)$.

Recently, a study in HF patients identified possible negative associations of serum sST2 with 25-hydroxyvitamin $\mathrm{D}(25(\mathrm{OH}) \mathrm{D})$ and 1,25-dihydroxyvitamin $\mathrm{D}$ $\left(1,25(\mathrm{OH})_{2} \mathrm{D}\right)$ serum levels and positive associations with parathyroid hormone (PTH). It also showed that 25(OH)D, 1,25 $(\mathrm{OH})_{2} \mathrm{D}$ and NT-proBNP were independent determinants of sST2 in a multiple regression analysis (16). Moreover, studies on primary human cells have shown that SST2 is predominantly secreted by lung epithelial cells and cardiac myocytes (17), while several other cell types, such as venous and arterial endothelial cells (18), as well as CD4 and CD8 lymphocytes (19), produce measurable amounts of the protein. Interestingly, all of these cells express the $1,25(\mathrm{OH})_{2} \mathrm{D}$-producing enzyme CYP27B1, as well as the vitamin D receptor $(20,21,22)$. Furthermore, a study on primary human lung epithelial cells and CD4 lymphocytes showed an increase in secretion of sST2 when treated with $1,25(\mathrm{OH})_{2} \mathrm{D}$, while the lung epithelial cells also responded to treatment with $25(\mathrm{OH}) \mathrm{D}$ with an increase in sST2 secretion (19).

It is currently unknown if vitamin $\mathrm{D}$ and/or seasonality affect the systemic levels of sST2 and therefore influence its usefulness as a biomarker or its clinical relevance. We hypothesized that vitamin D supplementation might alter the serum concentrations of sST2 and investigated a vitamin $\mathrm{D}$ intervention in hypertensive patients enrolled in the randomized, placebo-controlled Styrian
Vitamin D Hypertension Trial. In addition, we investigated sST2 concentrations measured cross-sectionally in hypertensive patients of the LURIC study for their potential changes due to the common seasonal variation of the measured $25(\mathrm{OH}) \mathrm{D}$ levels.

\section{Materials and methods}

This investigation was carried out in two cohorts involving hypertensive patients at cardiovascular risk, the Styrian Vitamin D Hypertension Trial and the Ludwigshafen Risk and Cardiovascular Health Study (LURIC). Both cohorts are described separately in the following section.

\section{Styrian vitamin D hypertension trial (study A)}

\section{Study design}

The first part of the present investigation was a post hoc analysis of the 'Styrian Vitamin D Hypertension Trial' (23). This intervention trial was designed as a doubleblind, placebo-controlled (1:1), single-centre study and took place at the outpatient clinic of the Division of Endocrinology and Diabetology, Medical University of Graz, Austria. The trial was registered at www. clinicaltrialsregister.eu (EudraCT number 2009-018125-70) and at clinicaltrials.gov (ClinicalTrials.gov identifier NCT02136771). The Ethics Committee of the Medical University of Graz, Austria, approved the study protocol and all participants gave written informed consent.

\section{Study population}

Participants were eligible to participate in the study at an age of 18 years or older with diagnosed arterial hypertension and a $25(\mathrm{OH}) \mathrm{D}$ baseline serum concentration below $30 \mathrm{ng} / \mathrm{mL}$. The main exclusion criteria were published previously (23). The sample size of at least 86 study participants per group was determined assuming a standardized effect size of 0.5 , for a two-sided alternative hypothesis with an $\alpha$ of 0.05 and a power of $90 \%$. Further details can be found in the publication of the original study (23). Recruitment took place from June 2011 to August 2014 and 200 Caucasian study participants (106 men and 94 women) were included. The present investigation presents 185 study participants, where sST2 measurements were available before and after vitamin D or placebo treatment.
This work is licensed under a Creative Commons Attribution-NonCommercial-NoDerivatives 4.0 enternationad ticense ifica.com at 04/26/2023 01:06:25PM 


\section{Intervention}

Study participants included in the study were randomly allocated to receive $2800 \mathrm{IU}$ cholecalciferol in the form of seven oily drops per day (Oleovit D3 drops, Fersenius Kabi Austria, Graz, Austria) or a matching placebo for 8 weeks. Hundred participants were allocated to the control group and 100 to the intervention group.

\section{Outcome measure}

The primary outcome measure in the current study was the between-group difference in serum SST2 concentrations at study end adjusted for baseline values.

\section{Measurements}

Blood samples were taken between 07:00 and 11:00 h in the morning after an overnight fast at both study visits. The samples were either measured by routine on-site laboratory procedures or stored at $-80^{\circ} \mathrm{C}$ until analysis. Measurements of serum 25(OH)D were performed by means of a chemiluminescence assay (IDSiSYS 25-hydroxyvitamin D S assay; Immunodiagnostic Systems Ltd., Boldon, UK) on an IDS-iSYS multidiscipline automated analyser with an intra-assay and inter-assay coefficient of variation (CV) of 6.2 and $11.6 \%$, respectively. SST2 was measured in serum with the Human ST2/IL-33 R Quantikine ELISA Kit (R\&D Systems). The intra-assay CVs were $4.5-5.6 \%$ and inter-assay CVs were $6.3-7.1 \%$, while the lower limit of detection was $5.1 \mathrm{pg} / \mathrm{mL}$ according to the manufacturer. PTH was measured using a sandwich ElectroChemiLuminescence Immunoassay (ECLIA) on an Elecsys 2010 immunoassay analyser (Roche Diagnostics), with inter-assay CVs 5.7-6.3\%. Measurements of other parameters have been described previously (23).

\section{LURIC study (study B)}

\section{Study design}

The second part of the present investigation was carried out as post hoc analysis of the LURIC study, a prospective study, which aimed to determine biochemical and genetic risk factors for coronary artery disease (CAD) in a hospitalbased cohort of Caucasian individuals who were referred for coronary angiography and in addition, to evaluate the predictive value of potential markers on long-term outcomes. The objectives of the study, recruitment procedures and characteristics have been described in more detail previously (24). The study protocol was approved by the Ethics Committee at the Landesärztekammer
Rheinland-Pfalz (Mainz, Germany) in accordance with the Declaration of Helsinki, and written informed consent was obtained from each participant.

\section{Study population}

No fixed sample size estimates were made for the LURIC study design at the time of conception because of its exploratory nature. Nonetheless, a sample size of $>3000$ was determined based on a power calculation with an $\alpha$ of 0.05 and a power of $80 \%$ as well as $90 \%$ and, in addition, because it was anticipated that also subsets of the entire population will be investigated. Please refer to (24) for further details. Overall, 3316 patients were enrolled in the LURIC study. Of these, 1403 hypertensive patients with available sST2, 25OHD, $1,25(\mathrm{OH})_{2} \mathrm{D}$ and PTH levels as well as NYHA and HF classification were included in the present analysis. The baseline examination protocols were described in detail previously (24). Arterial hypertension, defined as mean systolic and diastolic BP out of five measurements $>140 / 90 \mathrm{mmHg}$, was determined by brachial artery pressure value measurements with an automated oscillometric device (Omron MX4, Omron Health Care GmbH, Hamburg, Germany) after the patient had rested in the supine position for at least $10 \mathrm{~min}$. In addition, at least three consecutive systolic and diastolic BP measurements were taken with a minimum interval of $30 \mathrm{~s}$. Only measurements conforming to the reproducibility criteria were entered into the database.

\section{Outcome measure}

The main aim of the present post hoc analysis was to determine if there is an effect of seasonality on the levels of sST2, while also determining possible associations of vitamin D-related parameters with sST2.

\section{Measurements}

Venous blood samples were drawn after an overnight fast (between 08:00 and 10:00 h) before coronary angiography. Routine laboratory parameters were immediately measured on a daily basis as previously described (24). The remaining blood samples were centrifuged at $3000 \mathrm{~g}$ for $10 \mathrm{~min}$, aliquoted, frozen and stored at $80^{\circ} \mathrm{C}$ until further analysis within $30 \mathrm{~min}$ after venepuncture. sST2 was determined in EDTA plasma samples in one batch for all patient samples approximately 12 years after the recruitment period of the LURIC study was closed. SST2 was measured on a fully automated BEP 2000 instrument https://ec.bioscientifica.com https://doi.org/10.1530/EC-19-0090 (c) 2019 The authors Published by Bioscientifica Ltd
This work is licensed under a Creative Commons Attribution-NonCommercial-NoDerivatives 4.0 Internationab bicense.ifica .com at 04/26/2023 01:06:25PM 
(Siemens Healthcare Diagnostics) with the Presage ST2 sandwich immunoassay assay (Critical Diagnostics) with CVs of $4.0 \%$, as previously published (15). 25(OH)D levels were assayed weekly in serum samples using a commercial radioimmunoassay (DiaSorin SA) with intraassay and inter-assay coefficients of variation of 8.6 and 9.2\%, respectively. Further, 25(OH)D levels were previously determined in 100 randomly selected samples by liquid chromatography tandem mass spectrometry with isotopic labelled internal standard, which showed a highly significant correlation between the 25(OH)D levels obtained by RIA and liquid chromatography tandem mass spectrometry $(r=0.875 ; P<0.001)$. PTH was measured using a sandwich ElectroChemiLuminescence Immunoassay (ECLIA) on an Elecsys 2010 immunoassay analyser (Roche Diagnostics), with intra- and inter-assay CVs $1.5-2.7 \%$ and 3.0-6.5\%, respectively (25). 1,25(OH) 2 D levels were analysed in serum samples by RIA (Nichols Institute Diagnostika GmbH, Bad Nauheim, Germany) on a Berthold LB2014 multicrystal counter. A high-sensitivity ELISA assay (R\&D Systems Inc.) was used to measure the plasma levels of interleukin-6 (IL-6).

\section{Data analyses}

Continuous data following a normal distribution are reported as means with standard deviations (s.D.), while variables with a skewed distribution are shown as medians with interquartile ranges and categorical variables are shown as percentages of observations.

Groups at baseline were compared using unpaired Students $t$-tests, Mann-Whitney $U$ tests or chi-squared tests. Skewed variables were $\log$ transformed when appropriate before being used in parametrical statistical analysis. Spearman's correlation analyses were used to test for associations of parameters with sST2. Bonferroni correction was used to account for multiple comparisons.

Analysis of covariance (ANCOVA) with adjustments for baseline values was used to test for differences in the outcome variable (sST2) and 25OHD between the placebo and the treatment group at the follow-up visit.

ANOVA followed by the Bonferroni post hoc test was used to determine seasonal variability and to calculate which monthly mean values of $25(\mathrm{OH}) \mathrm{D}$ and sST2 were significantly different to the peak monthly mean. When the assumption of homogeneity of variances was not met, Welch ANOVA followed by the Games-Howell post hoc test was used instead. ANCOVA was used for group comparisons with adjustment for age, eGFR, BMI, IL-6 levels, T2DM status, smoking status, any previous myocardial infarctions, any previous strokes, transient ischaemic attacks and/or prolonged reversible ischaemic neurologic deficits.

If outliers were detected in the analyses by the software (for ANCOVA defined as cases with standardized residuals greater than \pm 3 S.D. and for ANOVA defined as cases with values higher or lower than $1.5 * \mathrm{IQR}$ (interquartile range)), they were removed and the analysis repeated to determine their potential effect on the analysis. If the outlier had no significant effect on the analysis, the results including the outlier are reported.

All variables from both studies were analysed without data imputation, for example in the Styrian Vitamin D Hypertension Trial, where only participants with both baseline and follow-up values of the respective outcome variable were included in the analyses.

A $P$ value of $<0.05$ was considered statistically significant in all analyses. All statistical analyses were performed using SPSS version 22 software (SPSS).

\section{Results}

Firstly, we set out to assess if vitamin D treatment affects sST2 levels. The baseline characteristics of the study A cohort can be found in Table 1 (top; study A). We found significant differences in sST2, serum calcium and serum phosphate between men and women at baseline. At baseline, there were no differences between the placebo and treatment groups between the parameters included in the study (data not shown). We found no significant correlations of baseline sST2 with $25(\mathrm{OH}) \mathrm{D}, 1,25(\mathrm{OH})_{2} \mathrm{D}$ or PTH neither in men $\left(r_{\mathrm{s}}=-0.033, P=0.746 ; r_{\mathrm{s}}=-0.124\right.$, $P=0.229 ; r_{\mathrm{s}}=0.062, P=0.543$; respectively) nor women $\left(r_{\mathrm{s}}=-0.191, P=0.077 ; r_{\mathrm{s}}=-0.187, \quad P=0.084 ; r_{\mathrm{s}}=-0.186\right.$, $P=0.084$; respectively) in the whole cohort and also not in a sub-cohort of study participants with baseline $25(\mathrm{OH}) \mathrm{D}$ levels below $20 \mathrm{ng} / \mathrm{mL}$ (or $<15 \mathrm{ng} / \mathrm{mL}$; data not shown) (Table 2; study A). sST2 correlated significantly also with eGFR in both men and women $\left(r_{\mathrm{s}}=-0.222\right.$, $P=0.028$ and $r_{\mathrm{s}}=-0.230, P=0.032$, respectively).

Vitamin $D$ supplementation induced a rise in $25(\mathrm{OH}) \mathrm{D}$ with a mean treatment effect $(95 \%$ confidence interval $(\mathrm{CI}))$ of $11.3(9.2-13.5) \mathrm{ng} / \mathrm{mL}(P<0.001)$, a rise in $1,25(\mathrm{OH})_{2} \mathrm{D}(9.5(4.9-14.0) \mathrm{pg} / \mathrm{mL} ; P<0.001)$ and $\mathrm{a}$ decrease in PTH (-5.9 (-9.4 to -2.2$) \mathrm{pg} / \mathrm{mL} ; P=0.002)$ as compared to placebo. The concentrations of sST2 remained unchanged in the whole cohort $(0.1 \quad(-0.6$ to 0.8$) \mathrm{ng} / \mathrm{mL} ; P=761$ ) and also in a sub-cohort of study participants with baseline 25(OH)D levels below

This work is licensed under a Creative Commons Attribution-NonCommercial-NoDerivatives 4.0 Internationad bicense ifica.com at 04/26/2023 01:06:25PM 
Table 1 Baseline characteristics in study A (top) and general characteristics in study B (bottom) according to gender.

\begin{tabular}{l}
\hline Study A \\
\hline Age (years) \\
BMI $\left(\mathrm{kg} / \mathrm{m}^{2}\right)$ \\
Gender $(\%$ female) \\
sST2 $(\mathrm{ng} / \mathrm{mL})$ \\
$25(\mathrm{OH}) \mathrm{D}(\mathrm{ng} / \mathrm{mL})$ \\
$\mathrm{PTH}(\mathrm{pg} / \mathrm{mL})$ \\
$1,25(\mathrm{OH})_{2} \mathrm{D}(\mathrm{pg} / \mathrm{mL})$ \\
Serum calcium $(\mathrm{mmol} / \mathrm{L})$ \\
Serum phosphate $(\mathrm{mmol} / \mathrm{L})$ \\
eGFR (mL/min/1.73 $\left.\mathrm{m}^{2}\right)$ \\
Active or previous smoker (\%) \\
Type 2 diabetes mellitus (\%) \\
Previous myocardial infarctions (\%) \\
Heart failure (\%) \\
C-reactive protein (mg/L) \\
Study B
\end{tabular}

Age (years)

BMI $\left(\mathrm{kg} / \mathrm{m}^{2}\right)$

sST2 $(\mathrm{U} / \mathrm{mL})$

25(OH)D (ng/mL)

PTH $(\mathrm{pg} / \mathrm{mL})$

$1,25(\mathrm{OH})_{2} \mathrm{D}(\mathrm{ng} / \mathrm{L})$

Serum calcium (mmol/L)

Serum phosphate $(\mathrm{mg} / \mathrm{dL})$

eGFR $\left(\mathrm{mL} / \mathrm{min} / 1.73 \mathrm{~m}^{2}\right)$

IL-6 (ng/L)

Active or previous smoker (\%)

Type 2 diabetes mellitus (\%)

Previous myocardial infarctions (\%)

Previous stroke, PRIND and/or TIA (\%)

Heart failure (\%)

C-reactive protein $(\mathrm{mg} / \mathrm{L})$
Gender (\% female)

\begin{tabular}{c}
\hline All $(n=185)$ \\
\hline $62.4(52.9-68.1)$ \\
$29.7(27.1-32.8)$ \\
47 \\
$13.3(10.0-17.5)$ \\
$21.9(17.1-25.7)$ \\
$49.1(39.6-62.9)$ \\
$48.3(37.4-63.6)$ \\
$2.3(2.2-2.3)$ \\
$2.9 \pm 0.5$ \\
$82.7 \pm 17.7$ \\
53 \\
37 \\
7 \\
0 \\
$1.8(0.9-3.5)$ \\
All $(n=1403)$ \\
$65.6(58.6-71.8)$ \\
$27.3(25.0-30.1)$ \\
35 \\
$19.2(15.4-24.6)$ \\
$15.5(10.0-22.9)$ \\
$30.0(22.0-41.0)$ \\
$33.7(25.3-42.6)$ \\
$2.3(2.3-2.4)$ \\
$3.5(3.1-3.9)$ \\
$83.6(69.2-97.1)$ \\
$3.3(1.9-6.1)$ \\
64 \\
36 \\
43 \\
11 \\
48 \\
$3.7(1.9-6.1)$ \\
\end{tabular}

$16.2(11.6-21.2)$

$21.4(15.2-25.9)$

$48.7(37.9-60.8)$

$50.9(39.2-64.6)$

$2.3(2.2-2.3)$

$2.7 \pm 0.5$

$84.7 \pm 16.6$

69

44

10

0

$1.8(0.9-3.4)$

Men $(n=994)$

64.9 (57.8-71.0)

$27.4(25.3-30.1)$

$$
\text { I }
$$

$19.8(16.0-25.4)$

$16.6(11.3-23.5)$

$29.0(22.0-39.0)$

34.6 (26.3-43.6)

$2.3(2.3-2.4)$

$3.4(3.1-3.7)$

83.6 (69.2-97.1)

$3.4(1.9-6.3)$

76

37

47

11

46

\begin{tabular}{|c|c|}
\hline Women $(n=87)$ & $P$ value \\
\hline $63.7(55.5-68.8)$ & 0.177 \\
\hline $29.3(27.1-33.2)$ & 0.568 \\
\hline I & 1 \\
\hline $11.6(9.0-15.3)$ & $<0.001$ \\
\hline $22.7(17.6-25.6)$ & 0.412 \\
\hline $51.4(41.6-64.0)$ & 0.181 \\
\hline $44.6(33.2-63.0)$ & 0.053 \\
\hline $2.3(2.2-2.4)$ & 0.033 \\
\hline $3.1 \pm 0.5$ & $<0.001$ \\
\hline $80.5 \pm 18.7$ & 0.107 \\
\hline 36 & $<0.001$ \\
\hline 29 & 0.033 \\
\hline 4 & 0.073 \\
\hline 0 & I \\
\hline $1.9(0.8-3.6)$ & 0.714 \\
\hline Women $(n=409)$ & $P$ value \\
\hline 67.7 (61.6-73.3) & $<0.001$ \\
\hline $26.9(24.4-30.2)$ & 0.008 \\
\hline I & / \\
\hline $17.3(14.4-22.6)$ & $<0.001$ \\
\hline $12.6(8.1-20.6)$ & $<0.001$ \\
\hline $32.0(24.0-44.0)$ & 0.001 \\
\hline $21.1(22.8-40.3)$ & $<0.001$ \\
\hline $2.3(2.3-2.4)$ & 0.683 \\
\hline $3.7(3.3-4.1)$ & $<0.001$ \\
\hline $83.6(68.5-98.6)$ & 0.824 \\
\hline $3.3(2.0-5.7)$ & 0.332 \\
\hline 33 & $<0.001$ \\
\hline 35 & 0.367 \\
\hline 33 & $<0.001$ \\
\hline 12 & 0.585 \\
\hline 54 & 0.065 \\
\hline $3.9(1.6-9.1)$ & 0.160 \\
\hline
\end{tabular}

$3.4(1.4-9.1)$
1,25(OH)D, 1,25-dihydroxyvitamin D; BMI, body mass index; eGFR, estimated glomerular filtration rate; 25(OH)D, 25-hydroxyvitamin D; PRIND, prolonged reversible ischaemic neurologic deficit; PTH, parathyroid hormone; SST2, soluble ST2; TIA, transient ischaemic attack.

Table 2 Baseline Spearman's correlations of the parameters from study A and study B with sST2 in all subjects included in the study as well as in subjects with 25(OH)D below $20 \mathrm{ng} / \mathrm{mL}$.

\begin{tabular}{|c|c|c|c|c|c|c|c|c|}
\hline \multirow[b]{3}{*}{ Study A } & \multicolumn{4}{|c|}{ SST2 (in all included subjects) } & \multicolumn{4}{|c|}{ sST2 (in subjects with $25(\mathrm{OH})$ D below $20 \mathrm{ng} / \mathrm{mL}$ ) } \\
\hline & \multicolumn{2}{|c|}{$\operatorname{Men}(N=96)$} & \multicolumn{2}{|c|}{ Women $(N=87)$} & \multicolumn{2}{|c|}{$\operatorname{Men}(N=37)$} & \multicolumn{2}{|c|}{ Women $(N=32)$} \\
\hline & Spearmans's rho & $P$ value & Spearmans's rho & $P$ value & Spearmans's rho & $P$ value & Spearmans's rho & $P$ value \\
\hline $25(\mathrm{OH}) \mathrm{D}$ & -0.033 & 0.746 & -0.191 & 0.077 & 0.080 & 0.633 & -0.190 & 0.299 \\
\hline $1,25(\mathrm{OH})_{2} \mathrm{D}$ & -0.124 & 0.229 & -0.187 & 0.084 & 0.021 & 0.904 & -0.313 & 0.081 \\
\hline PTH & 0.062 & 0.543 & -0.186 & 0.084 & 0.042 & 0.800 & -0.191 & 0.296 \\
\hline \multirow[b]{2}{*}{ Study B } & \multicolumn{2}{|c|}{ Men $(N=994)$} & \multicolumn{2}{|c|}{ Women $(N=409)$} & \multicolumn{2}{|c|}{ Men $(N=633)$} & \multicolumn{2}{|c|}{ Women $(N=301)$} \\
\hline & Spearmans's rho & $P$ value & Spearmans's rho & $P$ value & Spearmans's rho & $P$ value & Spearmans's rho & $P$ value \\
\hline $25(\mathrm{OH}) \mathrm{D}$ & $-0.106 *$ & 0.001 & -0.055 & 0.271 & $-0.143 *$ & $<0.001$ & -0.011 & 0.851 \\
\hline $1,25(\mathrm{OH})_{2} \mathrm{D}$ & -0.031 & 0.323 & -0.026 & 0.603 & -0.092 & 0.021 & -0.027 & 0.635 \\
\hline PTH & 0.084 & 0.008 & -0.008 & 0.879 & 0.092 & 0.021 & -0.020 & 0.735 \\
\hline
\end{tabular}

*Correlation coefficients significant also after Bonferroni correction.

1,25(OH)D, 1,25-dihydroxyvitamin D; 25(OH)D, 25-hydroxyvitamin D; PTH, parathyroid hormone; sST2, soluble ST2.

https://ec.bioscientifica.com https://doi.org/10.1530/EC-19-0090
(C) 2019 The authors Published by Bioscientifica Ltd

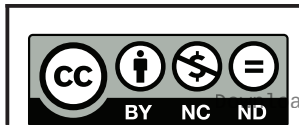

This work is licensed under a Creative Commons Attribution-NonCommercial-NoDerivatives 4.0 elnternationab bicense.ifica . com at $04 / 26 / 2023$ 01:06:25PM 
Table 3 ANCOVA analysis for the effect of vitamin D or placebo treatment on parameters from study A.

\begin{tabular}{|c|c|c|}
\hline Parameter & Group & Baseline \\
\hline \multirow[t]{2}{*}{$25(\mathrm{OH}) \mathrm{D}$} & Vitamin D & $23.0(19.0-26.3)$ \\
\hline & Placebo & $21.2(15.2-25.4)$ \\
\hline \multirow{2}{*}{$1,25(\mathrm{OH})_{2} \mathrm{D}^{*}$} & Vitamin D & $48.7(38.6-63.6)$ \\
\hline & Placebo & $46.4(35.4-63.5)$ \\
\hline \multirow[t]{2}{*}{ PTH* } & Vitamin D & $49.0(39.6-61.5)$ \\
\hline & Placebo & $51.4(39.2-63.9)$ \\
\hline \multirow[t]{2}{*}{ SST2* } & Vitamin D & $13.3(10.4-17.3)$ \\
\hline & Placebo & $13.5(9.4-18.3)$ \\
\hline \multirow{2}{*}{$\begin{array}{l}\text { sST2 in subjects with baseline } \\
25(\mathrm{OH}) \mathrm{D} \text { below } 20 \mathrm{ng} / \mathrm{mL}^{*}\end{array}$} & Vitamin D & $15.5(9.1-18.3)$ \\
\hline & Placebo & $15.9(10.1-18.7)$ \\
\hline \multirow[t]{2}{*}{ sST2 in men* } & Vitamin D & $16.5(13.1-19.2)$ \\
\hline & Placebo & $16.0(10.7-23.0)$ \\
\hline \multirow[t]{2}{*}{ sST2 in women* } & Vitamin D & $12.3(9.1-13.7)$ \\
\hline & Placebo & $11.4(8.8-16.2)$ \\
\hline
\end{tabular}

\begin{tabular}{l}
\hline Follow-up \\
\hline $35.4(16.3-28.5)$ \\
$23.0(30.4-42.1)$ \\
$58.8(46.2-69.3)$ \\
$48.6(35.4-59.6)$ \\
$45.5(37.8-54.3)$ \\
$50.6(38.6-66.1)$ \\
$13.8(10.6-17.1)$ \\
$12.8(9.2-17.4)$ \\
$14.7(9.9-19.4)$ \\
$13.7(10.4-18.0)$ \\
$15.1(12.9-20.2)$ \\
$15.4(10.4-22.4)$ \\
$11.6(8.9-13.8)$ \\
$11.9(9.0-13.7)$ \\
\hline
\end{tabular}

\begin{tabular}{|c|c|}
\hline $\begin{array}{c}\text { Treatment effect } \\
\text { (95\% confidence interval) }\end{array}$ & $P$ value \\
\hline $11.3(9.2-13.5)$ & $<0.001$ \\
\hline $9.5(4.9-14.0)$ & $<0.001$ \\
\hline$-5.9(-9.4$ to -2.2$)$ & 0.002 \\
\hline $0.1(-0.6$ to 0.8$)$ & 0.761 \\
\hline 0.4 (-1.3 to 2.1$)$ & 0.639 \\
\hline $0.3(-1.3$ to 1.9$)$ & 0.753 \\
\hline$-0.02(-1.2$ to 1.2$)$ & 0.977 \\
\hline
\end{tabular}

*Analyses where outliers were present but did not significantly affect the results.

1,25(OH)D, 1,25-dihydroxyvitamin D; 25(OH)D, 25-hydroxyvitamin D; PTH, parathyroid hormone; sST2, soluble ST2.

$20 \mathrm{ng} / \mathrm{mL}(0.4$ (-2.1 to 2.1$) \mathrm{ng} / \mathrm{mL} ; P=0.639)$ (Table 3 ) or $<15 \mathrm{ng} / \mathrm{mL}$ (data not shown).

Since the levels of sST2 differed between genders, we also tested if vitamin D had different effects on sST2 concentrations in men and women. There were no significant treatment effects on sST2 levels neither in men $(0.3(-1.3$ to 1.9$) \mathrm{ng} / \mathrm{mL} ; P=0.753)$ nor in women $(-0.02$ $(-1.2$ to 1.2$) \mathrm{ng} / \mathrm{mL} ; P=0.977$ ) (Table 3$)$.

Secondly, we wanted to determine if seasonal variation is present in sST2 levels. General characteristics of the study B cohort can be found in Table 1 (bottom; study B) and parameter values of subjects subgrouped according to gender as well as the meteorological definition of the seasons can be found in the supplement (Supplementary Table 4 , see section on supplementary data given at the end of this article). We found significant differences in age, BMI, sST2, 25(OH)D, PTH, 1,25(OH $)_{2} \mathrm{D}$ and serum phosphate.

We found significant correlations of sST2 levels with 25(OH)D $\left(r_{\mathrm{s}}=-0.106, P<0.001\right.$; significant after Bonferroni correction) in men, but not with $1,25(\mathrm{OH})_{2} \mathrm{D}$ and PTH; $r_{\mathrm{s}}=-0.031, \quad P=0.323 ; \quad r_{\mathrm{s}}=0.084, \quad P=0.008 ;$ respectively, both not significant after Bonferroni correction), while no significant associations were found in women $\left(r_{\mathrm{s}}=-0.055\right.$, $P=0.271 ; r_{\mathrm{s}}=-0.026, P=0.603 ; r_{\mathrm{s}}=-0.008, P=0.879$; for $25(\mathrm{OH}) \mathrm{D}, 1,25(\mathrm{OH})_{2} \mathrm{D}$ and $\mathrm{PTH}$, respectively) within the whole cohort (Table 2; study B). We made a similar observation in the sub-cohort of study participants with baseline 25(OH)D levels below $20 \mathrm{ng} / \mathrm{mL}$ (and < $15 \mathrm{ng} / \mathrm{mL}$; data not shown). We also detected significant correlations of sST2 with eGFR in both men and women $\left(r_{\mathrm{s}}=-0.194\right.$, $P<0.001$ and $r_{\mathrm{s}}=-0.194, P<0.001$, respectively).
Monthly variations were present in 25(OH)D levels in men and in women, with and without $\mathrm{HF}(P<0.001$ for all subgroups). There was a significant effect on sST2 in men with HF $(P=0.44)$, while sST2 levels remained unaffected by the seasons in men without HF and women with and without $\operatorname{HF}(P=0.895, P=0.512$ and $P=0.948$, respectively). When adjusted for age, eGFR, BMI, IL-6 levels, T2DM status, smoking status, any previous myocardial infarctions, any previous strokes, transient ischaemic attacks and/or prolonged reversible ischaemic neurologic deficits, the monthly seasonal variances remained significant in all subgroups for $25(\mathrm{OH}) \mathrm{D}$ ( $P<0.001$ for all groups), while they were not significant for sST2 in any of the subgroups (for men with HF, $P=0.073$, and without $\mathrm{HF}, P=0.803$; for women with $\mathrm{HF}, P=0.948$, and without $\mathrm{HF}, P=0.512$.

Median 25(OH)D and sST2 concentrations with 95\% CI in men and women, with and without HF are shown in Fig. 1. The levels of $25(\mathrm{OH}) \mathrm{D}$ peaked in August in both men and women with HF (median $23.2 \mu \mathrm{g} / \mathrm{L}$ and $20.8 \mu \mathrm{g} / \mathrm{L}$ respectively), in July in men without HF (median $24.4 \mu \mathrm{g} / \mathrm{L}$ ) and in August in women without HF (median $27.0 \mu \mathrm{g} / \mathrm{L})$. The lowest $25(\mathrm{OH}) \mathrm{D}$ values were observed in January in men with HF (median $8.1 \mu \mathrm{g} / \mathrm{L}$ ), in February in women with HF (median 6.6 $\mathrm{g} / \mathrm{L}$ ) and in March in men and women without HF (median $10.9 \mu \mathrm{g} / \mathrm{L}$ and $7.1 \mu \mathrm{g} / \mathrm{L}$, respectively).

sST2 concentrations were highest in May in men with HF (median $24.7 \mathrm{U} / \mathrm{mL}$ ), in February in women with HF (median 22.6U/mL) in January in men without HF (median 20.2 U/mL) and in March in women without HF (median 19.2 U/mL). The lowest levels of sST2 were found in June in men with HF (median 19.4 U/mL), in August

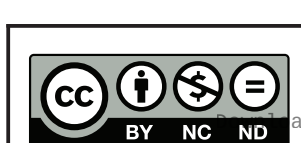

This work is licensed under a Creative Commons Attribution-NonCommercial-NoDerivatives 4.0 enternationab ticense:ifica.com at 04/26/2023 01:06:25PM 

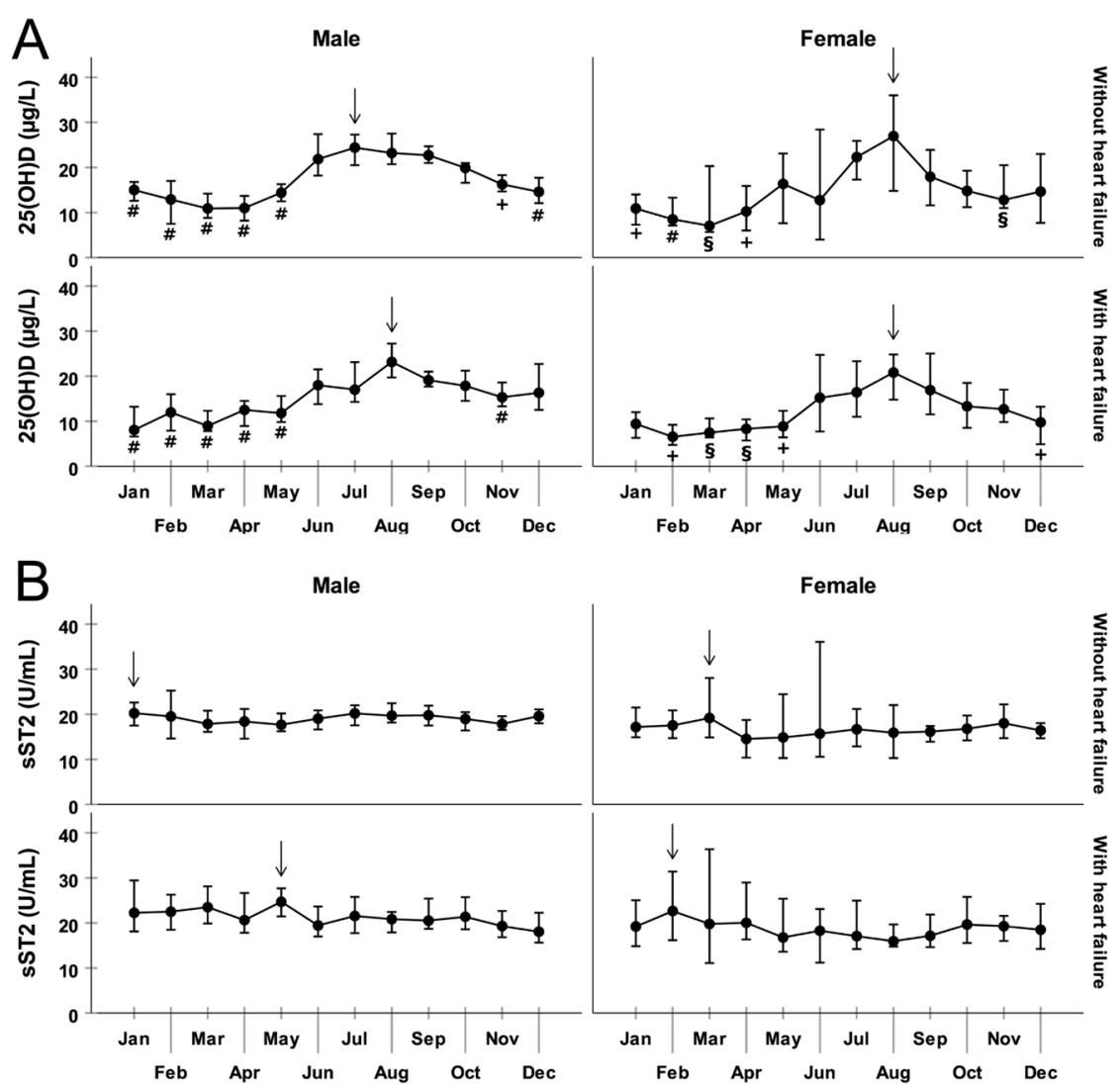

\section{Figure 1}

Seasonal variation in $25(\mathrm{OH}) \mathrm{D}(\mathrm{A})$ and $\mathrm{SST} 2(\mathrm{~B})$ concentrations (monthly median values with $95 \%$ $\mathrm{Cl}$ ) in men and women further subgrouped into subjects with and without heart failure in study $B$. Significant differences from the peak value $(\downarrow)$; ${ }^{\S} P<0.05 ;{ }^{+} P<0.01 ;{ }^{\#} P<0.001$. The data were log transformed before being used in ANOVA analyses. Outliers were present in all ANOVA analyses but did not significantly affect the results. in women with HF (median 20.0 U/mL), in May in men without HF (median 17.7 $\mathrm{U} / \mathrm{mL}$ ) and in April in women without HF (median $14.5 \mathrm{U} / \mathrm{mL}$ ).

\section{Discussion}

While several studies $(16,17,18,19,20,21,22)$ were pointing towards the possibility of sST2 levels being regulated by vitamin $\mathrm{D}$, our findings based on two nonrelated studies do not support an interrelation of sST2 levels with vitamin D levels or an influence of seasons on sST2 levels in subjects at cardiovascular risk. We found no effects of vitamin D intervention on the serum levels of sST2 in study A, even though both $25(\mathrm{OH}) \mathrm{D}$ and $1,25(\mathrm{OH})_{2} \mathrm{D}$ levels increased and PTH levels decreased in the treatment group. It is possible that we did not observe any vitamin $\mathrm{D}$ effects because the participants of study A had relatively low sST2 levels and in general did not suffer from severe CVD. For example, in patients with HF or myocardial infarction, in which sST2 level elevations have been shown to be higher $(6,7)$, the effects of vitamin $\mathrm{D}$ treatment might have been more pronounced. Also, vitamin D treatment might affect the
sST2-producing cells and change sST2 secretion locally in the target cell surroundings, as shown in experiments with primary human cells in culture (19), but the changes in sST2 secretion were not large enough to be detectable as differences in systemic levels. Additionally, also the fact that the subjects in study A were vitamin D insufficient and not severely vitamin D deficient might have contributed to our observed results. In general, the most plausible explanation could be that vitamin D treatment had no effect on sST2 secretion, which would be in tune with several recent meta-analyses of vitamin D RCT studies showing limited or no benefits on CVD events, mortality and various surrogate cardiovascular parameters (26).

The second aim of our study was to determine if sST2 levels follow a seasonal pattern relatable to that of $25(\mathrm{OH}) \mathrm{D}$. We predicted a distinct pattern of sST2 throughout the year, following that of vitamin D $(25(\mathrm{OH}) \mathrm{D})$, if sST2 levels were affected by vitamin D levels. Another possibility was the occurrence of its own distinct yearly pattern as observed with the commonly used cardiovascular biomarker NT-proBNP. It has been shown to be periodically elevated in summer months in primary care patients, although its seasonal pattern did not seem to match that of vitamin D, hypertension, total cholesterol or BMI (27). 
Further, since study B, as opposed to study A, also included patients with $\mathrm{HF}$, more pronounced effects might have been observed. Contrary to our predictions, the results showed that sST2 levels remained unchanged throughout the year in study B although the levels of $25(\mathrm{OH}) \mathrm{D}$ followed the expected seasonal patterns $(28,29,30)$ in both genders. Although one of the unadjusted statistical tests found significant differences in men with HF, after adjusting for several parameters including age and eGFR, we believe these differences are not biologically relevant (for example, the biggest difference in adjusted log transformed sST2 level means was $0.132 \log (\mathrm{U} / \mathrm{mL})$ between the months March and July). In general, we also observed similar results when the subjects in study B were subgrouped according to the meteorological definition of the seasons (Supplementary Fig. 2) and when comparing the shapes of the graphs (Supplementary Fig. 3). This observation, in addition to the fact that the results obtained by analysing study $B$ that stem from a separate cohort than the vitamin D treatment experiments, reiterates that vitamin $\mathrm{D}$ seems to have minimal or no effect on systemic levels of sST2. In addition, our results support the notion that sST2 levels might not fluctuate as a result of external environmental influences, such as changes in ambient temperature that have been proposed to play a role in the observed seasonality of CVD (1).

We also observed differences between genders in the month in which the levels of $25(\mathrm{OH}) \mathrm{D}$ started to rise when also taking into account whether these patients suffered from HF. This was observed earlier in women (May) than in men (June) without HF and could have been a consequence of different outdoor activity levels throughout the year between men and women without $\mathrm{HF}$ in our study population. In subjects of both genders with HF 25(OH)D levels started to rise in June, indicating that HF itself probably impacts the outdoor activity of the subjects to a similar degree. Nonetheless, we found higher median 25(OH)D levels in men when not stratifying for HF. A similar observation was also made in a cohort of patients undergoing coronary angiography and concluded that gender differences in $25(\mathrm{OH}) \mathrm{D}$ levels might have a relevant role in severity of CAD (31).

Interestingly, we found significant associations of sST2 concentrations with $25(\mathrm{OH}) \mathrm{D}$ in study B in men but not in women, while we found no correlations in study A. The lack of associations of vitamin D-related parameters in study A may be due to the fact that the subjects did not have as severe cardiovascular disease complications as in study B and the study published by Gruson et al. This study in HF patients, where associations with sST2 were analysed in the whole cohort without stratification into genders (16), made similar observations to ours in study B and found correlations not only with $25(\mathrm{OH}) \mathrm{D}$ and $\mathrm{PTH}$, but also with $1,25(\mathrm{OH})_{2} \mathrm{D}$. Substantially lower $1,25(\mathrm{OH})_{2} \mathrm{D}$ levels have been observed in $\mathrm{HF}$ (32), which was also found for the HF patients in the aforementioned study $(24.0 \mathrm{pg} / \mathrm{mL})$ (16), compared to our study (48.3 pg/mL in study A and $33.7 \mathrm{pg} / \mathrm{mL}$ in study B). This difference might have contributed at least in part to the lack of observed associations in studies $\mathrm{A}$ and $\mathrm{B}$. The contrasting associations found in studies $\mathrm{A}$ and $\mathrm{B}$ might also be explained by the difference in cohort size and this difference in size could also be the reason we found contrasting differences in baseline parameter levels between men and women in our two studies.

Our study has some limitations, namely, that the results stem from post hoc analyses of both studies A and B. In addition, the inclusion of vitamin $\mathrm{D}$ insufficient hypertensives only in study $\mathrm{A}$ and patients referred for coronary angiography in study B could mean that the conclusions cannot be readily extrapolated to the general population. While a growing body of research is available on the role of sST2 in hypertension and several other CVD, it is not as established to be a potential prognostic or diagnostic marker as in HF. Despite that, the results on the effects of seasonality on sST2 we obtained from hypertensives with and without $\mathrm{HF}$ were very similar. Of note, measurements of sST2 in study A and B were performed with different methods which are not standardised and at present cannot be directly compared to each other. Nonetheless, both showed the expected differences in sST2 levels between the genders $(33,34)$, with higher sST2 levels measured in men than in women, confirming the reliability of both measurements. Other strengths of our study include the RCT design of study A with a successful vitamin $\mathrm{D}$ intervention, the cohort size of study B with data collected over several years, as well as broad and reliable parameter measurements in both studies A and B. Lastly, the results from two non-related cohorts pointing towards the same conclusion further underline the validity of our findings.

In summary, we show that systemic sST2 levels are not influenced by vitamin $\mathrm{D}$ treatment in vitamin $\mathrm{D}$ insufficient hypertensive subjects. We also show that sST2 levels do not change in parallel to 25(OH)D levels and exhibit no significant fluctuations throughout the year in subjects referred to coronary angiography irrespective of whether they did or didn't have HF. Our study provides the first evidence that vitamin D levels are not interrelated with systemic sST2 levels in subjects with cardiovascular

This work is licensed under a Creative Commons Attribution-NonCommercial-NoDerivatives 4.0 Internationab ticense.ifica.com at 04/26/2023 01:06:25PM 
disease. While it still remains to be elucidated, if the same holds true for the general population, our study gives further confidence that sST2 could be used as a biomarker also in the clinical setting throughout the year.

\section{Supplementary data}

This is linked to the online version of the paper at https://doi.org/10.1530/ EC-19-0090.

\section{Declaration of interest}

The authors declare that there is no conflict of interest that could be perceived as prejudicing the impartiality of the research reported.

\section{Funding}

The Styrian Vitamin D Hypertension Trial was supported in part by funding from the Austrian National Bank (Jubilaeumsfonds: project no.: 13878 and 13905). V Francic was supported by the PhD programme Molecular Medicine at the Medical University of Graz, Graz, Austria. BioPersMed (COMET K-project 825329) provided a part of the analysis equipment. LURIC has received funding from the 6th Framework Program (integrated project Bloodomics, grant LSHM-CT-2004-503485) and from the 7th Framework Program (Atheroremo, grant agreement number 201668 and RiskyCAD, grant agreement number 305739) of the European Union.

\section{Acknowledgements}

The authors would like to thank all study participants. They also thank Fresenius Kabi for providing the study medication, Cornelia Missbrenner for contributions to sample management, Andrea Wöls for assistance with laboratory analysis, Dr Ingrid Gergei for assistance with data analysis as well as Katharina Eberhard and Dr Andrea Groselj-Strele for advice on statistics.

\section{References}

1 Stewart S, Keates AK, Redfern A \& McMurray JJV. Seasonal variations in cardiovascular disease. Nature Reviews: Cardiology $2017 \mathbf{1 4}$ 654-664. (https://doi.org/10.1038/nrcardio.2017.76)

2 Norman PE \& Powell JT. Vitamin D and cardiovascular disease. Circulation Research 2014114 379-393. (https://doi.org/10.1161/ CIRCRESAHA.113.301241)

3 Marti-Soler H, Gubelmann C, Aeschbacher S, Alves L, Bobak M, Bongard V, Clays E, de Gaetano G, Di Castelnuovo A, Elosua R, et al. Seasonality of cardiovascular risk factors: an analysis including over 230000 participants in 15 countries. Heart 2014100 1517-1523. (https://doi.org/10.1136/heartjnl-2014-305623)

4 Sanada S, Hakuno D, Higgins LJ, Schreiter ER, McKenzie AN \& Lee RT. IL-33 and ST2 comprise a critical biomechanically induced and cardioprotective signaling system. Journal of Clinical Investigation 2007117 1538-1549. (https://doi.org/10.1172/JCI30634)

5 Pascual-Figal DA, Lax A, Perez-Martinez MT, del Carmen AsensioLopez M, Sanchez-Mas J \& GREAT Network. Clinical relevance of SST2 in cardiac diseases. Clinical Chemistry and Laboratory Medicine 201654 29-35. (https://doi.org/10.1515/cclm-2015-0074)

6 Shimpo M, Morrow DA, Weinberg EO, Sabatine MS, Murphy SA, Antman EM \& Lee RT. Serum levels of the interleukin-1 receptor family member ST2 predict mortality and clinical outcome in acute myocardial infarction. Circulation 2004109 2186-2190. (https://doi. org/10.1161/01.CIR.0000127958.21003.5A)
7 Weinberg EO, Shimpo M, Hurwitz S, Tominaga S, Rouleau JL \& Lee RT. Identification of serum soluble ST2 receptor as a novel heart failure biomarker. Circulation 2003107 721-726. (https://doi. org/10.1161/01.CIR.0000047274.66749.FE)

8 Wang Y, Tan X, Gao H, Yuan H, Hu R, Jia L, Zhu J, Sun L, Zhang H, Huang L, et al. Magnitude of soluble ST2 as a novel biomarker for acute aortic dissection. Circulation 2018137 259-269. (https://doi. org/10.1161/CIRCULATIONAHA.117.030469)

9 Andersson C, Preis SR, Beiser A, DeCarli C, Wollert KC, Wang TJ, Januzzi JL Jr, Vasan RS \& Seshadri S. Associations of circulating growth differentiation factor-15 and ST2 concentrations with subclinical vascular brain injury and incident stroke. Stroke $2015 \mathbf{4 6}$ 2568-2575. (https://doi.org/10.1161/STROKEAHA.115.009026)

10 Kjeldsen SE. Hypertension and cardiovascular risk: general aspects. Pharmacological Research 2018129 95-99. (https://doi.org/10.1016/j. phrs.2017.11.003)

11 Velagaleti RS \& Vasan RS. Heart failure in the twenty-first century: is it a coronary artery disease or hypertension problem? Cardiology Clinics 200725 487-495; v. (https://doi.org/10.1016/j. ccl.2007.08.010)

12 Ho JE, Larson MG, Ghorbani A, Cheng S, Vasan RS, Wang TJ \& Januzzi JL Jr. Soluble ST2 predicts elevated SBP in the community. Journal of Hypertension 201331 1431-1436; discussion 6. (https://doi. org/10.1097/HJH.0b013e3283611bdf)

13 Ates I, Ozkayar N, Ates H, Karakulak UN, Kursun O, Topcuoglu C, Inan B \& Yilmaz N. Elevated circulating SST2 associated with subclinical atherosclerosis in newly diagnosed primary hypertension. Hypertension Research 201639 513-518. (https://doi.org/10.1038/hr.2016.16)

14 Farcas AD, Anton FP, Goidescu CM, Gavrila IL, Vida-Simiti LA \& Stoia MA. Serum soluble ST2 and diastolic dysfunction in hypertensive patients. Disease Markers 20172017 2714095. (https:// doi.org/10.1155/2017/2714095)

15 Dieplinger B, Egger M, Haltmayer M, Kleber ME, Scharnagl H, Silbernagel G, de Boer RA, Maerz W \& Mueller T. Increased soluble ST2 predicts long-term mortality in patients with stable coronary artery disease: results from the Ludwigshafen risk and cardiovascular health study. Clinical Chemistry 201460 530-540. (https://doi. org/10.1373/clinchem.2013.209858)

16 Gruson D, Ferracin B, Ahn SA \& Rousseau MF. Soluble ST2, the vitamin D/PTH axis and the heart: new interactions in the air? International Journal of Cardiology 2016212 292-294. (https://doi. org/10.1016/j.ijcard.2016.03.063)

17 Mildner M, Storka A, Lichtenauer M, Mlitz V, Ghannadan M, Hoetzenecker K, Nickl S, Dome B, Tschachler E \& Ankersmit HJ. Primary sources and immunological prerequisites for SST2 secretion in humans. Cardiovascular Research 201087 769-777. (https://doi. org/10.1093/cvr/cvq104)

18 Bartunek J, Delrue L, Van Durme F, Muller O, Casselman F, De Wiest B, Croes R, Verstreken S, Goethals M, de Raedt H, et al. Nonmyocardial production of ST2 protein in human hypertrophy and failure is related to diastolic load. Journal of the American College of Cardiology 200852 2166-2174. (https://doi.org/10.1016/j. jacc.2008.09.027)

19 Pfeffer PE, Chen YH, Woszczek G, Matthews NC, Chevretton E, Gupta A, Saglani S, Bush A, Corrigan C, Cousins DJ, et al. Vitamin D enhances production of soluble ST2, inhibiting the action of IL-33. Journal of Allergy and Clinical Immunology 2015135 824.e3-827.e3. (https://doi.org/10.1016/j.jaci.2014.09.044)

20 Zehnder D, Bland R, Chana RS, Wheeler DC, Howie AJ, Williams MC, Stewart PM \& Hewison M. Synthesis of 1,25-dihydroxyvitamin D(3) by human endothelial cells is regulated by inflammatory cytokines: a novel autocrine determinant of vascular cell adhesion. Journal of the American Society of Nephrology 200213 621-629.

21 Razzaque MS. The dualistic role of vitamin D in vascular calcifications. Kidney International 201179 708-714. (https://doi. org/10.1038/ki.2010.432) 
22 Kongsbak M, Levring TB, Geisler C \& von Essen MR. The vitamin D receptor and T cell function. Frontiers in Immunology 20134148 (https://doi.org/10.3389/fimmu.2013.00148)

23 Pilz S, Gaksch M, Kienreich K, Grubler M, Verheyen N, FahrleitnerPammer A, Treiber G, Drechsler C, OH B, Obermayer-Pietsch B, et al. Effects of vitamin D on blood pressure and cardiovascular risk factors: a randomized controlled trial. Hypertension $2015 \mathbf{6 5}$ 1195-1201. (https://doi.org/10.1161/ HYPERTENSIONAHA.115.05319)

24 Winkelmann BR, Marz W, Boehm BO, Zotz R, Hager J, Hellstern P, Senges J \& LURIC Study Group (LUdwigshafen RIsk and Cardiovascular Health). Rationale and design of the LURIC study - a resource for functional genomics, pharmacogenomics and long-term prognosis of cardiovascular disease. Pharmacogenomics 20012 (1 Supplement 1) S1-S73. (https://doi.org/10.1517/14622416.2.1.S1)

25 Tomaschitz A, Pilz S, Ritz E, Grammer T, Drechsler C, Boehm BO \& Marz W. Independent association between 1,25-dihydroxyvitamin D, 25-hydroxyvitamin D and the renin-angiotensin system: the Ludwigshafen Risk and Cardiovascular Health (LURIC) study. Clinica Chimica Acta 2010411 1354-1360. (https://doi.org/10.1016/j. cca.2010.05.037)

26 Zittermann A. Vitamin D status, supplementation and cardiovascular disease. Anticancer Research 201838 1179-1186. (https://doi. org/10.21873/anticanres.12338)

27 Khezri BS, Cederblad M, Helmersson-Karlqvist J, Karlsson B, Melhus H \& Larsson A. Seasonal variability of NT-proBNP in Swedish primary care patients. Chronobiology International 201734 1473-1477. (https://doi.org/10.1080/07420528.2017.1366500)

28 Klenk J, Rapp K, Denkinger MD, Nagel G, Nikolaus T, Peter R, Koenig W, Bohm BO \& Rothenbacher D. Seasonality of vitamin
D status in older people in Southern Germany: implications for assessment. Age and Ageing 201342 404-408. (https://doi. org/10.1093/ageing/aft042)

29 Klingberg E, Olerod G, Konar J, Petzold M \& Hammarsten O. Seasonal variations in serum 25-hydroxy vitamin D levels in a Swedish cohort. Endocrine 201549 800-808. (https://doi. org/10.1007/s12020-015-0548-3)

30 Kasahara AK, Singh RJ \& Noymer A. Vitamin D (25OHD) serum seasonality in the United States. PLOS ONE 20138 e65785. (https:// doi.org/10.1371/journal.pone.0065785)

31 Verdoia M, Schaffer A, Barbieri L, Di Giovine G, Marino P, Suryapranata H, De Luca G \& Novara Atherosclerosis Study Group (NAS). Impact of gender difference on vitamin D status and its relationship with the extent of coronary artery disease. Nutrition, Metabolism, and Cardiovascular Diseases 201525 464-470. (https:// doi.org/10.1016/j.numecd.2015.01.009)

32 Zittermann A \& Ernst JB. Calciotropic and phosphaturic hormones in heart failure. Nutrition, Metabolism, and Cardiovascular Diseases 201626 971-979. (https://doi.org/10.1016/j.numecd.2016.06.007)

33 Dieplinger B, Januzzi JL Jr, Steinmair M, Gabriel C, Poelz W, Haltmayer M \& Mueller T. Analytical and clinical evaluation of a novel high-sensitivity assay for measurement of soluble ST2 in human plasma - the Presage ST2 assay. Clinica Chimica Acta: International Journal of Clinical Chemistry 2009409 33-40. (https:// doi.org/10.1016/j.cca.2009.08.010)

34 Miller AM, Purves D, McConnachie A, Asquith DL, Batty GD, Burns H, Cavanagh J, Ford I, McLean JS, Packard CJ, et al. Soluble ST2 associates with diabetes but not established cardiovascular risk factors: a new inflammatory pathway of relevance to diabetes? PLoS ONE 20127 e47830. (https://doi.org/10.1371/journal.pone.0047830)

Received in final form 18 April 2019

Accepted 29 April 2019

Accepted Preprint published online 29 April 2019 https://ec.bioscientifica.com https://doi.org/10.1530/EC-19-0090 (c) 2019 The authors Published by Bioscientifica Ltd
This work is licensed under a Creative Commons Attribution-NonCommercial-NoDerivatives 4.0 Internationab sicense.ifica . com at 04/26/2023 01:06:25PM 